\title{
生活行動の実態からみたオープン・コモンの働きと適応性に関する考察
}

\section{A STUDY ON THE USE AND ADAPTABILITY OF OPEN COMMON AS VIEWED FROM THE ACTUAL SITUATIONS OF LIVING ACTIVITIES}

\author{
大橋 寿美子*1, 小谷部 育子*2, 高 橋 䉆志*3 \\ Sumiko OHASHI, Ikuko KOYABE and Takashi TAKAHASHI
}

\begin{abstract}
This paper describes the use and adaptability of OC (Open Common) spaces, based on the analysis of actual situations of living activities. The results revealed the following:

1) A wide variety of activities were observed in OC spaces and OC spaces promoted the creation of habitation networks.

2) In addition to the inhabitants, OC space users included neighbors and an unspecified number of other people. Furthermore, habitation networks center on the activities of the inhabitants, although a wide range of variations existed depending on the situation.

3) OC spaces of the path/yard type had a role that enables the widest habitation network and could be flexibly adapted to situational changes.

4) OC spaces were adapting flexibly, and three types of $O C$ space changes were observed (e.g. changes in the quality, dominate function, and physical area of the OC space).
\end{abstract}

\section{Keywords : Open common, living activity, Habitation network, Adaptability, nLDK オープン・コモン 生活行動 居住ネットワーク 適応性 n L D K}

\section{1. はじめに}

\section{(1) 研究の背景と目的}

一連の本研究の目的は、多様な家族の生活双似に適応する居住祅 トワークの形成のための、柔軟で開かれた住居計画の構築への示唆を提 示することである。

少子高齢化、女性の社会進出、産業構造の変化は、生活不价を変 化させ、nLDK という住居形式がモデルに想定していた「夫婦と子から なる子育て期の核家族」以外の単身者、高齢者夫婦、共働きの家族、 選択した人との非血縁家族など多様な住み手の出現を促している。 家族や生活不仪の多様化により、住宅を拠点として、家族成員以外 の人やサービスなどに家族機能の一部を依存する生活双价を支える、居 住补ワーク形成の必要性が高まっている。しかし、現実の住宅供給は 核家族を対象とした $\mathrm{nLDK}$ の平面計画が中心であり、現在の家族の生 活実態が必要とする空間構成とのずれが顕在化している。既稿注11 では、これからの多様な家族の生活双价に対応し、自立した生活や 子育て環境を生み出寸居住祀忓㹥2)（以下居住 NT）の形成のため の、柔軟で開かれた Open Common 注3) が求められているとした仮説 を立てた。その上で、Open Common（以下 OC）をもつ住空間構成を 類型化し、その構成䏠“゙の実際の作品分析への適用を試みた。

本稿では、 $O C$ 領域が実際に生活の中でどのように使われている のか、状況に応じた個人と集住体社4) や身近な地域社会との関係に 柔軟に適応する場となっているのか、ということについて検証を行 う。具体的には、 $O C$ 領域をもつ住宅設計が近年増えてきており、そ れらの空間特性の傾向を把握した上で、OC 領域にみる生活行動の実 態調查から、居住 NT 形成の様相を考察する。また、多様な生活行動
が行われる状況に対して、OC 領域の質変化の実態を確認し、適応性 について考察する。最終的にこれらの検討結果から、改めて nLDK が想定した機能分化や家族構成による室機能の設定と現在の生活実 態との不適応の状況を明らかにすることで、既稿にて提示した $O C$ 領域をもつ構成紊”゙の有效性を確認寸る。

本論文に関連する住宅における生活行動および生活領域の実態 について取り扱った研究には、生活行動圈における近隣交流の実態 を明らかにした研究辣5)、住居内における行動と空間との対応関係 を統計的データ解析により求めたもの社 6)、住機能の都市化に視点を あて都市の生活関連价うを利用した生活行動の実態把握を試みたも の注7)、などがみられる。また住宅ではないが高齢者施設における 生活領域の広がり翟8〉を検討した研究がある。いずれも住宅内外に またがった生活行動を取り扱うものではない。本研究では、前稿で 論じた個人と社会との日常的なつながりが個人の自立を支えるとい う視点から、住宅を拠点として住宅内や住宅外、また内外にまたが るOC領域における生活行動を明らかにする。具体的には、住宅の内 部と外部空間及び敷地周辺を対象とした屋外にある $○$ について、利 用者の生活行動の実態から居住 NT のの $O C$ の働きかけや $O C$ 領域の状 況変化一の適応を明らかにするものである。

\section{2. 研究方法と調查概要}

近年、OC をもつ事例は建築家による住宅設計の中に徐々に現れて きている。そこで、まず近年の $O C$ 領域をもつ住宅設計にみる空間的 な特徴について全体傾向を把握し、その後、了解を得た住宅につい て居住者へのヒアリング調査と観察調查から OCにおける生活行動や領
*1 日本女子大学大学院 博士課程後期 - 修士 (家政学)

*2 日本女子大学家政学部住居学科教授・王博

*3 日本大学総合科学研究所 教授. 工博
Doctor Course Student, Graduate Japan Women's University, M.H.E.

Prof., Japan Women's University, Dr. Eng.

Prof., Japan University Research Center, Dr. Eng. 
域形成の実態を把握する。対象事例抽出方法や調查項目など調査概 要は表 1 にまとめた。

\section{OC をもつ住宅設計事例の特性}

\section{（1）全体傾向調查にみる空間特街}

全体傾向調查は実態調查の予備調查として位置づけ、近年の $O C$ をもつ事例の空間的傾向を以下の 6 点にまとめる。(1) $\propto$ をもつ事 例件数は現状ではまだ少ないが近年は増加傾向にある（1995～00 年 30 件、2001 03 年 62 件／全掲載住宅数 444 件)。(2)設計者が住宅を 拠点として個人と社会の接点を意図した $O C$ 領域に該当する空間は、 北゙ングやキッチンなどの住宅内や、縁側や土間などの内外の中間領域、 庭や敷地外の前面道路や路地までみられた（図 1)。(3) 構成領域の 配列仕 11) は 8 割が適応型 $\left(88 / 113 O C\right.$ 領域数主 $\left.{ }^{22)}\right)$ で、中でも動線 の選択性があるIV-B が最も多い (53/113 件、表 3)。(4) 住宅形態は 戸建て、戸建て集合、小規模集合、などの小規模なものが多い。(5) OC の空間形状は被包含型、通り庭型、前庭型、包含型の 4 タイ に大き く分かれ、さらに細かくみると 9 多价に分類できる主13)。事例数は、 オーフン〜クローズの間に位置した「通り庭型」が最も多くみられた（表 2)。(6) 空間配列と空間形状を吅した分析では、「IV-B×通り庭型」 が最も多い（29/113 件、表 2)。
(2)(3)6に示した特徵は、nLDK にみられない空間配列の状況を具 体的に示している。(2)で示したように、設計者は住宅内外を合わせ て生活領域ととらえ、個人と集住体以外の人との日常的な接点を $O C$ 領域でつくるという提案がみられた。

\section{（2）実態調査の対象事例の傾向 （表 3 参照）}

実態調查の対象事例の内訳は、戸建住宅である 3 事例以外の 13 事例は、小規模集合住宅、戸建集合、複数世帯居住（いわゆる2〜3 世帯住宅）である。さらに居住者家族の関係をみると、戸建住宅で ある 3 事例は核家族、小規模集合住宅は 7 事例で非血縁、2.3世帯 住宅は 4 事例（町屋 project を 1 事例として）で血縁の親族世帯で の居住である。核家族で戸建住宅の場合は、特に $O C$ 領域は地域との つながりを意図していることが特徴的で、小規模集合住宅や複数世 帯居住の $O C$ 領域の場合は居住者間のつながりに重点をおいて設計 されている。

また $O C$ 空間形状別の事例数は通り庭型 (町屋 project を 1 事例と して）と被包含型が各 5 事例、前庭型 2 事例、包含型が 2 事例、混 合が 1 事例であった。配列 $\times$ 形状をみると「IV-B×通り庭型」が最 も多い。近年の $O C$ をもつ住宅設計事例の全体傾向に近い空間配列の 傾向がみられる。

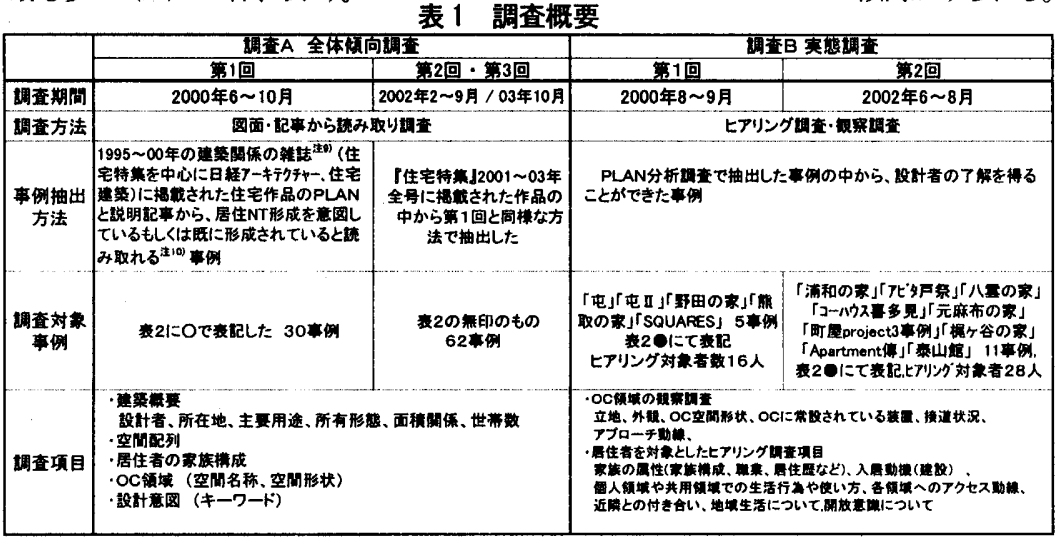

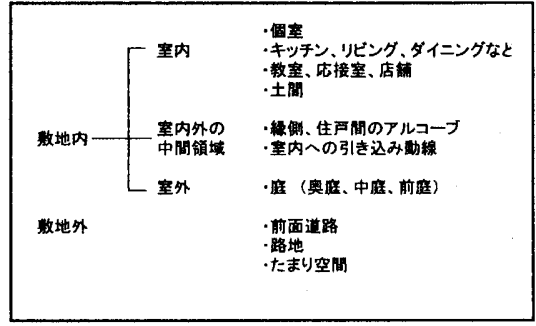

図 1

OCの空間名称の分類

表 2 配列 $\times O C$ 領域形状

※ マス内の数字は該当するOC領域O件数 $\mathrm{O}:$ 調查 $\mathrm{A}$ 第 1 回対象事例, 丸無：榙查 $\mathrm{A}$ 第 2.3 回対象事例 0 : 調查 $\mathrm{B}$ 対象事例

\begin{tabular}{|c|c|c|c|c|c|c|c|c|c|c|c|}
\hline & & OC形状 & & 被包含型 & & 通的庭 & & 前庭型 & & 包含型 & \\
\hline & & & A & $\mathrm{B}$ & $c$ & D & $E$ & $\mathrm{~F}$ & a & $\mathrm{H}$ & 1 \\
\hline 配 & 列 & & & 网 & 聯 & 戴 & & 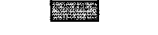 & & & \\
\hline 共 & 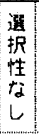 & III-A & 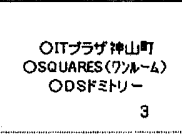 & 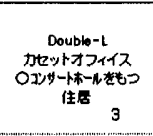 & 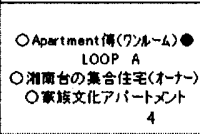 & 㮛一谷の㝵(子) & 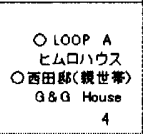 & 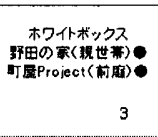 & $\begin{array}{r}\text { 䔬业の事 } \\
1\end{array}$ & 0 & 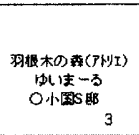 \\
\hline 型 & $\begin{array}{l}\text { 邀 } \\
\text { 性 } \\
\text { 有 }\end{array}$ & & $\begin{array}{r}\text { Pleats } \\
\quad 1\end{array}$ & 0 & HAT & 0 & ! & 0 & 0 & 0 & 0 \\
\hline & $\begin{array}{l}\text { 避 } \\
\text { 柱 } \\
\text { な } \\
\text { し }\end{array}$ & $N-A$ & 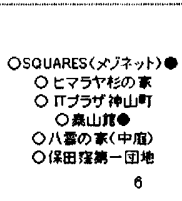 & 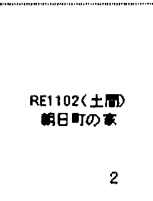 & 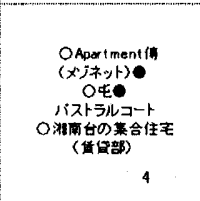 & 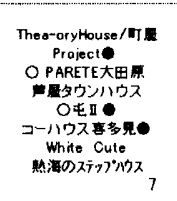 & 台形面の & 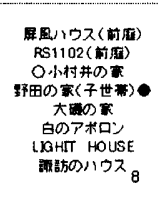 & 0 & 0 & 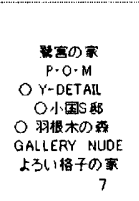 \\
\hline $\begin{array}{l}\text { 適 } \\
\text { 忘 } \\
\text { 型 }\end{array}$ & 措 & $\mathrm{Pe}^{\prime}$ & GREEN FOREST & 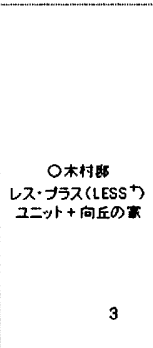 & 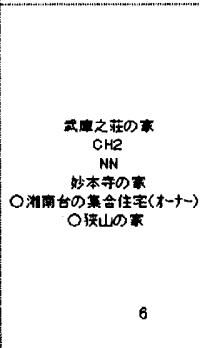 & 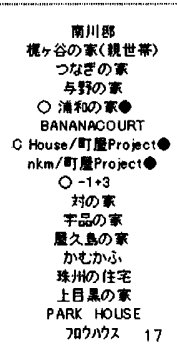 & 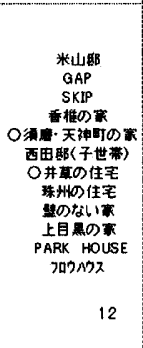 & 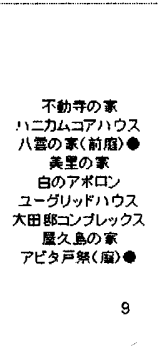 & S-HOUSE & 0 & 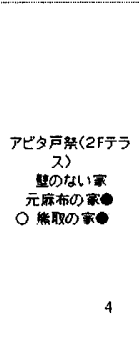 \\
\hline
\end{tabular}




\section{表 3 実態調查対象事例の概要と分析結果}

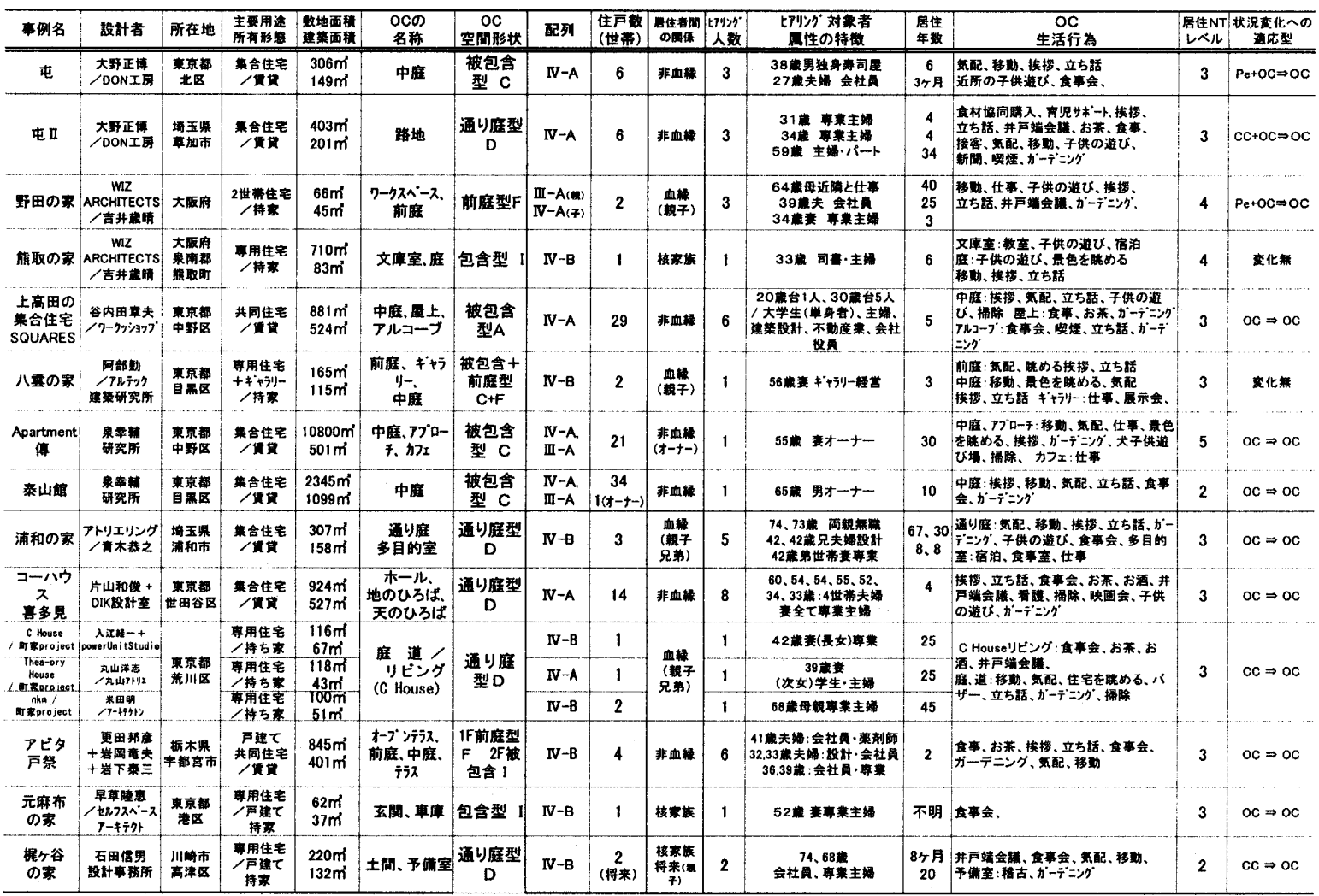

表 4 OC 領域にみる生活行為別人数

4. オープン・コモンでの生活行動と居住ネットワークの広がり 既稿 ${ }^{2}$ 1) にて、OC 領域があることで生まれる居住 NT の働きを「個 人の自立を支える」交流を生む」㽞い「生きがいに分類したが、 その具体的な行為項目注 14) を示した（表 4)。

(1)「個人の自立」を支える 外部からのサービスや相互扶助の場が確 保されることで、家族以外の人が家事・育児・介護を一部担うこと が容易になり、自立した生活を保障する。また仕事の関係者との接 客行為も自立した生活につながる。

(2)「交流」を生む内外を緩やかにつなぎ、外部に対する連続性 や開放性をもつことで、個人の集住体間また個人の集住体以外の人 にも共用領域として認識され種々の交流を生む場となる。

(3)「賏い」 今までプライベートな空間で行われてきた行為が開放的 な Open Common に進出し、生活のゆとりを生む場となる。またほっ とできる帰属意識を生む場となり、愛着に結びつく。

(4)「生きがい」ボランテ仍とどの社会活動や趣味など自己表現や確 認の場となる。積極的な社会活動の場や帰属意識を生む場となる。

事例ごとに $O C$ 領域での実際の生活行為について調查分析結果を 表 3 にまとめた。事例の中から、 $O C$ 領域で多様な生活行為がみられ た 6 事例の平面図に実際の生活行為を記入した(図 2 6 次頁以降)。

\section{(1) 生活行為別人数}

$O C$ 領域で行われていた生活行為の全体的な傾向をみる。調査対象 者本人が OC 領域で行っている行為およびその人が目撃した行為に ついてヒアリン゙調查を行い、行為別に人数を加外した（表 4) 注15)。そ の結果、 $O C$ 領域では多様な行為が行われていることがわかった。居 住 NT の働き項目別では「交流」が最も多くみられ、Oでみられる

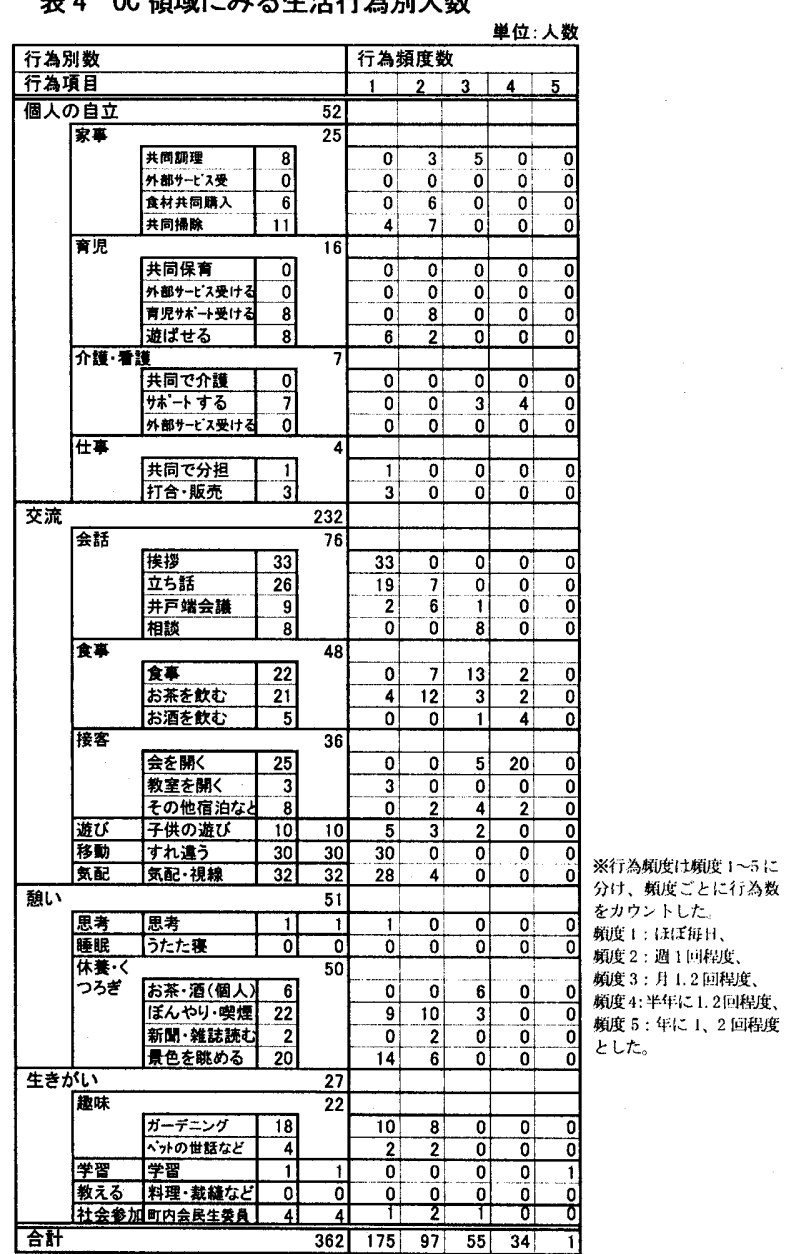


行為の過半数以上をしめている。次いで「個人の自立」款い」と続 き、「生きがい」に関する行為は若干しかみられない。また現状では 家事、育児、介護に関寸る「外部比゙スの利用」はみられない。さら に行為別にみると、挨拶や立ち話などの「会話」が最も多く、「休養・ くつろぎ」、お茶なども含めた「食事」、「気配」、「接客」「移動（す れ違い)\}の順に続く。このように現状での居住 NT の働きは「交流」 が最も多く「個人の自立」はあまりみられないが「交流」は相互理 解の原点であり、必要に応じて相互扶助を生み「個人の自立」を支 えあう居住 NT に発展していくことが予想される。

また、日常的な生活行為が居住 NT の形成を促す重要な要素となる ため、行為ごとに頿度注 16) をみた。頻度 $1 、 2$ を日常的行為、頻度 3、4、5 を非日常行為としてみると、日常的項目が 7.5 割と大半を しめている。特に行為数が多かった項目の頻度をみると「挨拶」「移 動」「気配」はほぼ毎日、「家事」「育児」「休養・くつろぎ」「趣味」 は毎日もしくは週 1、2回と、日常的に行われている。「食事」は頻 度にばらつきがみられる。「接客」の中でも人が集まる会などは半年 に 1.2 回程度が多く、非日常的行為といえる。このように生活行為 別人数が多い項目は総じて行為頻度も高く、日常的な生活行為であ った。

\section{（2）居住 NT の広がりレベルと生活行動}

$O C$ での生活行為を $O C$ の利用者別に分析することで、居住 NT の広 がりと生活行動を明らかにする。事例ごとの調査結果は表 3 に記し た。

\section{＜居住 NT の広がりレベル＞}

居住 NT の広がりをOCの利用者によって示すこととする。利用者 は、居住者の集住体のメバー、居住者の友人、近隣の人、通りすがり の人など不特定多数の人までみられ、利用者の組み合わせによって

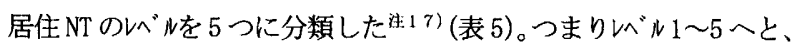
個人から集住体という枠をこえて同じ住宅の居住者へ、さらにその 友人、近隣の人、不特定多数の人一と祅俩夯広がっていく。居住 NT のレベごとに、事例でみられた生活行為とOC 領域の空間名称を 表 6 にまとめた。OC 領域の空間名称別にみると、室外の庭（中庭・ 前庭）で、もっとも多くの多様な行為が行われていた。

以下にレ゙ルごとに ○にたける特徵的な生活行動を中心にとりあ げる。

\section{<レベル 1 ： 個人的行動>}

個人で行う行動には、従来主に住宅内の個室で行われていた思考、 ダ仁グで行われていた食事、休養・くつろぎや移動という行為がみ られる。このような、思考、休養・くつろぎといった個室や北゙ッグ など住宅内や集住体内で行われていた行為が、居心地の良さから $0 C$ 領域へと表出されてきている。中庭、玄関前のアルコー゙、、屋上で個人 的行動がみられ、行動を誘発する椅子、ベンチ、テーブルなどの装置が置 かれている。これらの行為が最も多く見られるのは天気の良い休日 で、平日でも仕事を終えた後くつろぐ姿がみられる。事例では被包 含型の「SQUARES」図 2、「屯」や通り庭型の「屯II図 3、「浦和の 家」図 5 でみられる。「SQUARES」「屯」では単身者が、「屯II「浦和 の家」では集住体のメンバーが家族から離れて一人でくつろぐ姿が 多くみられる。個人的行動は他者と直接関わることなく一人で行う 行動だが、OCでの個人的行動が居住者間や近隣の人との挨拶や立ち 話など自然発生的な交流を生み出すきっかけとなっていた。
表 5 居住 NT の広がりレベル

\begin{tabular}{|c|c|}
\hline レベル & 利用者 \\
\hline レベル1 & 居住者個人 \\
\hline レベル2 & 集住体のメンパー(複数) \\
\hline レベル3 & 集住体のメンパー＋友人＋居住者 \\
\hline レベル4 & 集住体のメンバー＋友人＋居住者 + 近隣の人 \\
\hline レベル5 & 集住体のメンバー+ 友人 + 居住者 + 近隣の人 + 不特定多数 \\
\hline
\end{tabular}

表 6 生活行為がみられる OC 領域の空間名称(居住NT広がりのレベル別)

\begin{tabular}{|c|c|c|c|c|c|c|c|c|c|c|c|c|c|c|c|}
\hline \multirow{2}{*}{\multicolumn{3}{|c|}{ OC領域の空間名称 }} & \multicolumn{5}{|c|}{ 室内 } & \multicolumn{4}{|c|}{ 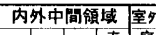 } & \multicolumn{4}{|c|}{ 票地外 } \\
\hline & & & 䁖 & $\begin{array}{l}\neq \\
y \\
z \\
y\end{array}$ & $\begin{array}{l}\frac{1}{1} \\
\frac{1}{3} \\
3\end{array}$ & 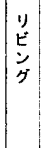 & 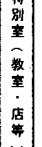 & 青 & 䙓 & \multicolumn{2}{|c|}{ 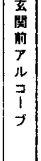 } & 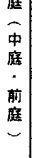 & $\begin{array}{l}\text { 教 } \\
\text { 地 } \\
\text { 道 } \\
\text { の } \\
\text { 爑 }\end{array}$ & $\mid \begin{array}{l}\text { 前 } \\
\text { 面 } \\
\text { 道 } \\
\text { a }\end{array}$ & \begin{tabular}{|l} 
路 \\
地
\end{tabular} \\
\hline \multirow{9}{*}{ 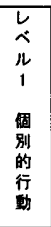 } & 思费 & 硣元ことをする & & & & & & & $\mathrm{OC}$ & 0 & 0 & & & & \\
\hline & & 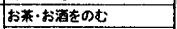 & & & & & 0 & & & O & काc & & & & \\
\hline & 休㟡 & 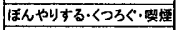 & & & & & 0 & & 0 & 0 & 50 & 5 & & & \\
\hline & •〈うろき & 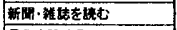 & & & & & & & & O & 50 & & & & \\
\hline & & 角色を伥める & & & & & 0 & & $\mathrm{O} / \mathrm{C}$ & $\mathrm{O}$ & $0 / 6$ & & & & \\
\hline & 敏味 & 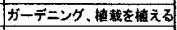 & & & & & & & 0 c & 0 & 010 & 5 & & & \\
\hline & 真事 & 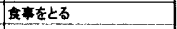 & & & & & & & $\mathrm{c}$ & o & 5) & 5 & & & \\
\hline & 移動 & 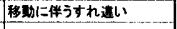 & & & - & & & & & & o. & 0.5 & & o. & \\
\hline & 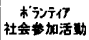 & 町内要貝やPTA，バザー & & & & & & & & & $c$ & 0 & & & \\
\hline 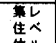 & 商児 & |子汼を遊|゙゙せる & & & & & & & & & $c$ & 0 & & & \\
\hline 内2 & 萐 & 友事をとる & & & 0 & 0 & 0 & & & 0 & 0 & 0 & & & \\
\hline & 家事 & 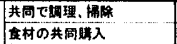 & & 0 & & & & & & & $c$ & & & & \\
\hline & 曹児 & 子㘫を避はせる & & & & 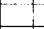 & & 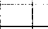 & & & c & 5 & & & \\
\hline$\hat{\lambda}$ & 会辞 & 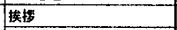 & & & & & & & & 7 & 0 & 5 & 5 & of & \\
\hline 3 & & 立与铦をする & & & & & & 0 & & & $0 \mid c$ & 0 & & o & \\
\hline & & 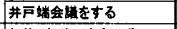 & & & & & & 0 & & & $\mathrm{o}$ & 으․ & & & \\
\hline 居 & 食㲤 & お苏、おやつるをくるる & 0 & & & 0 & & & 0 & 0 & o & o & & & \\
\hline 住 & & 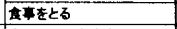 & $\mathrm{O}$ & & 0 & 0 & 0 & & & 0 & $\underline{0}$ & o & & & \\
\hline 者 & 接客 & 会(イベント圭件す & 0 & & 0 & 0 & & & & 0 & T & o & & & \\
\hline 间 & & 宿泊 なと & & & & & 요 & & & & & & & & \\
\hline 行 & 避U & 子非爑が遊心 & & & & 0 & & & & & 0 & o & & & \\
\hline & 移䵢 & 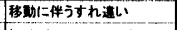 & & & & & & & & & o & of & j & o. & \\
\hline & 気配 & 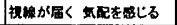 & & & & 0 & $\cdot$ & & & & s & o & & & \\
\hline L & 家事 & 克林の其同䋖入 & & & & & & & & & 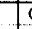 & O & & & \\
\hline$\dot{0}$ & 世事 & 任のの打各わせ 植党 & & & & & 이 & & & & & & & & \\
\hline$ル$ & 会話 & 糜控 & & & & & & & & & j & 0 & & 0 & 0 \\
\hline 4 & & 立ち話をする & & & & & & 0 & & & o & o & & o & 0 \\
\hline 近 & & 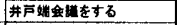 & & & & & & & & & & 0 & & & \\
\hline 祭 & 食事 & お夰、おやつを直へるる & & & & 0 & & & $\mathrm{O}$ & O & & 0 & & & \\
\hline 㒻 & & 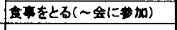 & 0 & & & 0 & 이 & & $c$ & 0 & o & o & & & \\
\hline 影 & 遊U & 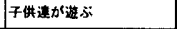 & & & & & & & & & 0 & 0 & & & \\
\hline 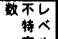 & 秘動 & 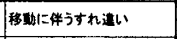 & & & & & & & & & o & sentas & & 0 & \\
\hline 35 & $\begin{array}{l}\text { 休率 } \\
\langle つ ろ き 己\end{array}$ & 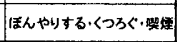 & 0 & & & & 0 & & $0: 1$ & $0 \mathrm{c}$ & 0 & 0 & & & \\
\hline
\end{tabular}
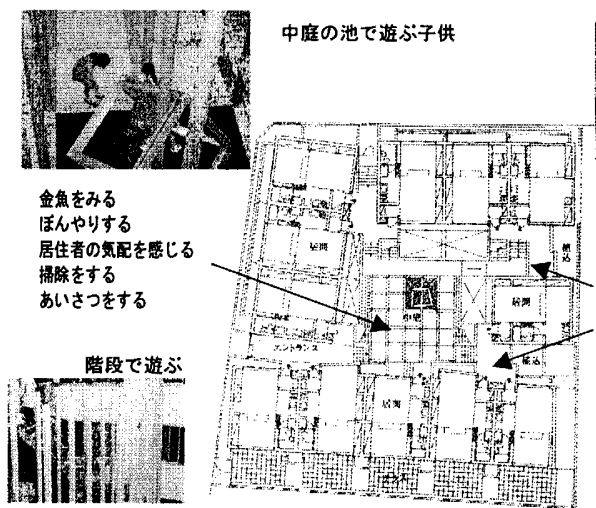

SQUARES $1 \mathrm{~F}$ 平面图
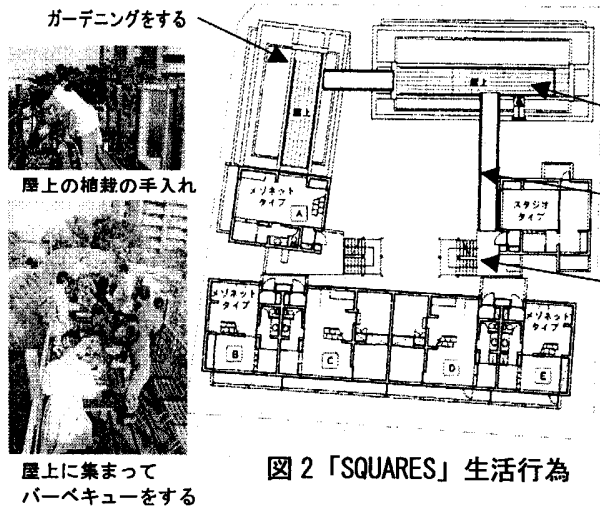

図 2 「SQUARES」生活行為

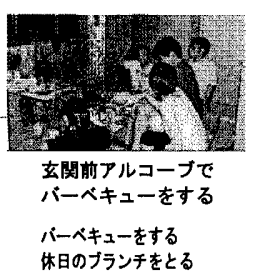

タバコをすう お莱を畔む

2x+8 1 .

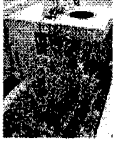

殿上の水道 と植载

バーベキューをする サーフボードを洗う ガーデニングをする 子供がランチを食べる ばラっとする 夜にタバをを吸う ふとんを干す お莱を飭む 敦人と铦をする 搭撜をする

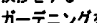

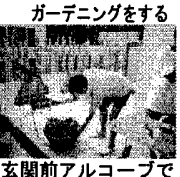




\section{くレベル 2： 集合的行動一集住体内行動＞}

集住体内行動は、従来通り北゙ング、ダ仁年でで行なわれることが 多く、OC 領域でみられた行為は育児と食事の 2 行為のみであった。 育児については、住宅内からも視線が届く $O C$ 領域で安心して日常的 に子供を遊ばせる。さらに、遊んでいる姿をみかけけた供が遊びに 加わるなど、子供間だけでなく親同士の交流を促し、以゙ル3や4 と発展していく様子がみられる。この行為がみられる具体的な空間 名称は中庭や前庭、ワークスベースがある。また食事については、集住体 のッハバーでバーベキューなどベントとしての食事を行う姿が中庭や屋上な どでみられる。このような行為がみられる事例は、育児は「屯

「野田の家」、食事は「泰山館」「SQUARES」であった。

\section{くレベル 3：集合的行動一居住者間行動＞}

集住体を超えて居住者間をつなぐ居住者間行動は、 $O C$ 領域で最も 多くみられる行動である。日常的行動と非日常的行動とに分けてみ ると、共同での調理は非日常の行動であるが、食材の分配、子供を 遊ばせる、挨拶、立ち話、井戸端会議、移動、気配を感じるという 行為は、日常的行為である。また食事は日常にも非日常にもみられ る行為だが、親族複合居住では利用頻度が上がり日常的な行為であ る。このような居住者間行動は全ての事例でみられ、食事や調理は

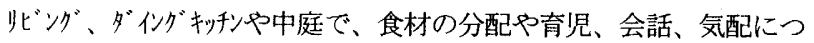
いては中庭、路地、土間でみられる。次に具体的に行為ごとに下記 に記す。

- 家事 : 掃除、共同調理、共同購入がみられる。掃除は当番や自主 的にしているもの、共同調理は親族居住による一つの䇛ンで共同で 複数世帯の料理を行うもの、共同購入は居住者と近隣の人との生協 などの食材の共同購入品の分配作業がみられる。

・子育て : 住戸内から子供が遊んでいる様子がみえるので、親は安 心して遊ばせることができる。また一緒に他の集住体の子供と遊ぶ 機会が増え、子供達は遊んでいる傍らで親同士が子供の様子を見が てら会話をする光景もみられる。このようにル゙ル2の行動が居住者 閒のつながりを生んでいる。「浦和の家」では以前、営んでいた店で 地域の子供を預かり、ちょっとした外出時や近所の共働き家族の為 の託児所の役割を果たしていた。

・会話 : レベル1の個人的行動の表出が、居住者間の挨拶や立ち話 を自然発生的に生んでいる。特に空間装置としてのべ沃や椅子のあ る「屯II「SQUARES」といった事例では、井户端会議などの滞在時 間が長い行為がみられる。

・食事 : 集住体内の食事と異なり、友人を呼んで、また居住者が集 まって食事をとる光景がみられる。親族複合居住ではより頻繁であ るが、非血縁の居住者同士でも親しい友人世帯の集住である「ュ-ハウ 又喜多見」では、食事やお茶を飲む行為が日常的にみられる。いずれ

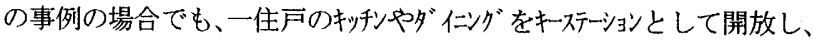
キッチッやダ 仁グと中庭やアルコーブなどが一体化して OC 領域をなし、食 事が行われる。

・気配 : 視線が届くか否かが気配を感じるか否かにかかわり、空間 形状や構成材の素材が関倸する。特に $O C$ 空間形状が被包含型や通り 庭型でかつ開口部が広く視線が通る「屯」「SQUARES」「屯II「町屋 Pro」「浦和の家」で柱、室内にいても $O C$ 領域やその奥にある他の居 住者の住戸の気配を適度に感じる。また「屯川」では高齢単身者の 安否をそれとなく気遣ったり、「町屋Pro」「浦和の家」では両親の
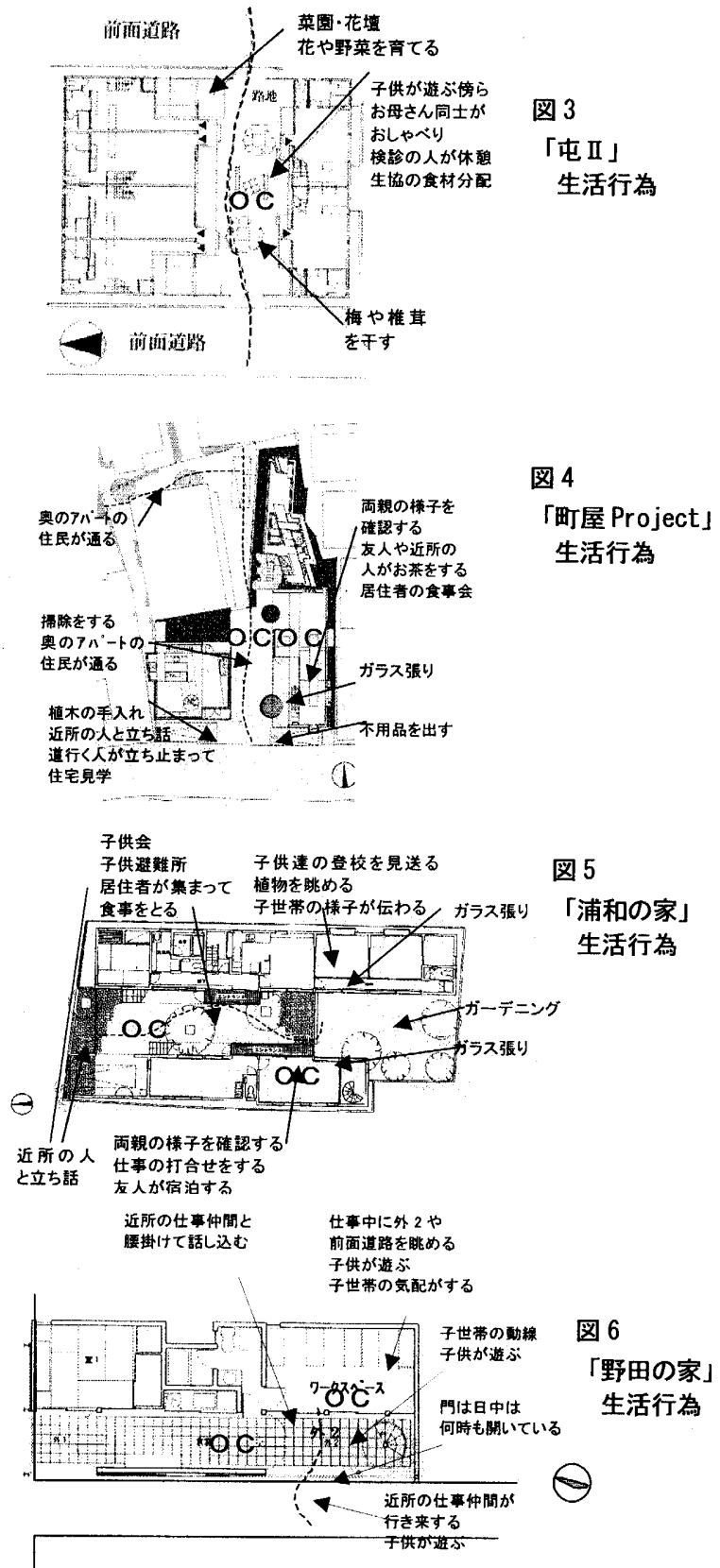

様子を気にかけることができている。居住者閒の様子がなんとなく わかるだけでなく、視線が通ることによる斘师や安心感、帰属感 につながっている。

・移動（動線の重なり）:日常の生活動線の重なりから、他の居住者 と日常的に顔を合わせて挨拶するといった自然な交流が始まる。被 包含型や通り庭型の事例では、居住者間の動線が重なり、交流が生 まれやすい形状と言える。

\section{<レベル 4：集合的行動一近隣者行動＞}

居住者の居住歴が長い $\propto$ 領域は、近隣の人の利用がみられる。 中でも居住歴約 40 年の「野田の家」では、师アスの縫製の仕事を分業 している近隣の仕事仲間の人が頻繁に出入し、仕事の打合せや日常 会話を行うなど、前庭とワークスペースが地域に開かれている。また、「町 屋Chouse」の师゙ングでは近隣の親しい人が集まり、食事会やお余会 が行われる。「浦和の家」の中庭や多目的室では、ル゙ル3でみられた 居住者間による食事の場に通りかかった近隣の人が合流する光景も みられる。近隣の人との会話、家事、食材の共同購入などや子供が 
遊ぶなどの行為はレベ 3 の居住者間行動の広がり行動である。 <レベル 5 ：個人的行動・集合的行動一不特定多数の人の行動> 不特定多数の人の利用は、主に単独行動が中心で、郵便配達の人 や水道検診の人などサービスを行う人、通りすがりの通行人などである。

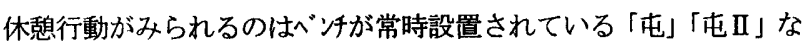
どである。がラス張りで外部から住戸内部に視線が通る「町屋 Chouse」 では、通行人が住宅を眺める姿がみられる。このような見知らぬの 人の行動を住戸内から居住者が見ており、視線が行き届き日常の生 活動線上に $O C$ 領域が存在しているからこそ不特定多数の利用を許 しているという関係が確認できた。

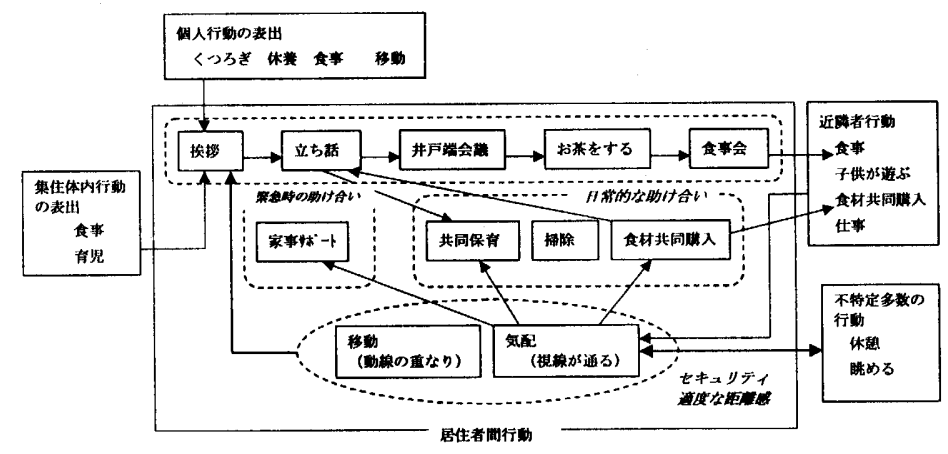

図 7 居住NT レベル間行動の関係図

レベル〜5までの生活行動の実態を総合的にみると、レベルの居住 者間をつなぐ NT が NT の中核をなしていた。OC の動線の重なりや $O C$ の気配を住戸内から感じることで、個人的行動や集住体内行動の表 出が居住者間 NT を生み出す。またその安定した居住者間 NT から生 まれた行動の表出が、近隣の人たちとの接点となり、补ワークの広が りをつくっていた。居住祇ワークレベ間の行動関係を図 7 にまとめた。

居住 NT 形成の流れを生活行動の実態から 整理すると、「ア切㣫線の重なり」や「視 線が通る」といった日常的な生活行動は、 「挨拶」や「立ち話」といった自然発生的な交

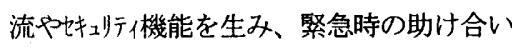
がみられ安心感や帰属感につながっている。 さらに現状では若干ではあるが、安心感や 帰属感をもつた安定した関係が日常的な相 互扶助を生み出していた。このように多様 な行為を受け止める $O C$ 領域をもつことに よる居住 NT の形成が確認できた。この居 住 NT の形成は、自立した生活や子育て環 境を生み出寸個人の自立の確立に発展して

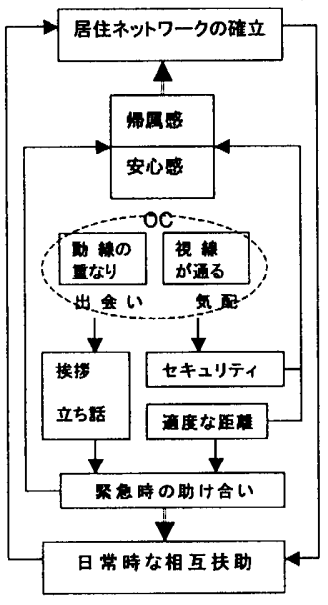
いくことが予想される。

図 8 居住祉形成の流れ

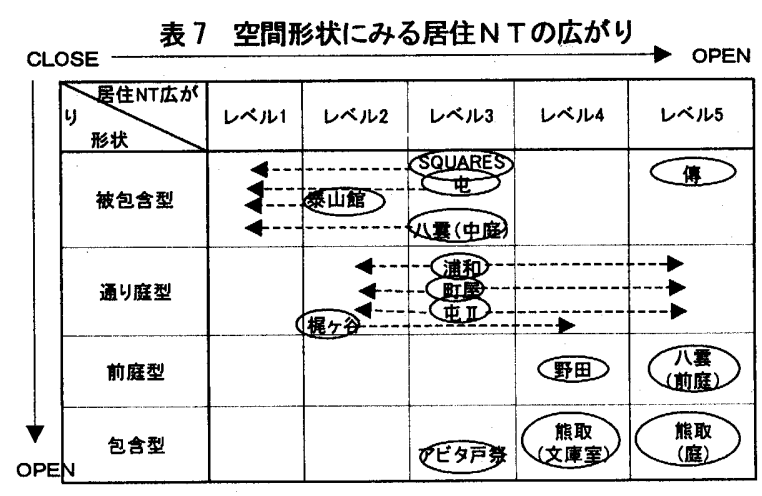

- 被包含型 : 被包含型は $O C$ 領域を住戸がとり囲む形状で、閉鎖的 な形状であるため、限定された居住者間での利用が本来適してい るといえる。視線が常に住戸内から届き、玄関からの夗瑀線が 重なる「SQUARES」「屯」「泰山館」では、集住体内か居住者間行 動が中心となっており、中庭に面した喫茶室が付随している「傳」 以外は地域や不特定多数の人への広がりがみられない。

・通り庭型 : 最も多くの行為がみられた、柔軟に状況に適応する形 状である。また被包含型同様、視線が常に住戸内から届き、玄関 からのア㲺動線が重なり、密接で安定的な親族世帯による居住者 間行動が NT の中核である。この安定的な NT が、状況に忍じて近 隣の人、通りすがりの人までと、多様な利用者を許容し状況によ る NT の広がりにつながっている。なお、「梶ヶ谷の家」では将来 の複数世帯を想定して作られているが現在は単世帯で居住のた めレヘル2が中心である。

・前庭型 : 事例ではレベル 4 と 5 がみられる。開放的である半面、柔 軟な選択性は持ちにくい形状であるため、地域とのつながりを持 ちやすいが、個人的行動や居住者間行動が行い難い。前庭型 $O C$ では近隣との交流や相互扶助がみられる。

・包含型 : $O C$ 領域が住宅を取り囲む最も開放的な形状であるが、居 住 NT は全てレ゙ル5 ではなく、居住者の開放意識によりル゙ル3〜 とばらつきがみられる。また開放的な形状であるため、逆にい゙ル 1.2 の個人的行動や集住体内行動がみられ難い。ル゙ル 5 の「熊取 の家」では、塀がない郊外の広い庭が住宅を囲み、文庫室を地域 の人へ、庭を不特定多数の人一開放している。

空間形状㚈ごとの居住 NT の広がりについて特徽を総じてみる と、通り庭型は居住 NT の広がりに柔軟性がみられ、状況による変化 への適応性がみられた。つまり、個人と他者との適度な距離感が筑 き易い形状といえる。また、形状と居住 NT の広がりとに概ね相関関 倸がみられ、オープンな形状ほど居住 NT のレベルが高く広がりがみら れた。

5. オープン・コモンの適応性

利用者の多様な行為にどのように $\propto$ 領域が適応しているのか、 領域の質や広がりの変化について検討する。

調査結果から、特別室など $O C$ 領域の機能を限定し、質や広がりに 変化がみられないもの（変化無）以外で、OC の領域変化を大きくわ けると、(1) $O C \Rightarrow O C$ (平常時とイベン時の変化) (2) $C C \Rightarrow O C$ (3) CC+OC $\Rightarrow O C$ (4) $\mathrm{Pe}+O C \Rightarrow O C$ の 4 つのパタンがみられた（表 8)。表には、居住 NT のレベルも明記し状況に応じた NT の広がり変化がわかるようにし 
た。

$<$ (1) $O C \Rightarrow O C$ (平常時とれベ溡の変化) $>$

$O C$ 領域の領域自体の広がりに変化はないが、領域の使用者と使わ れ方が変化する。平常時は、居住者の個人的行動や集住体メバー間で の行動がみられる。対して目的がはっきりとした食事会などの价ン 卜時では集住体メハバーと他の居住者や友人が利用者に加わり居住 NT が広がる。この場合の居住 NT の広がりに伴う領域の質の変化を可能 としているものには、居住者間の安定した関係による居住 NT が形成 されていることがベースにある。食事会などの价ントはにに一回程度み られるものが事例では多い。

<(2) $\mathrm{CC} \Rightarrow \mathrm{OC}$ への変化 $>$

(1)同様に $O C$ 領域の領域自体の伸縮はないが、集住体の領域 $C C$ が 集住体以外の人が利用可能な $O C$ へ変化するものである。日常的に 集住体のメバーの友人や地域の人が集まってくる他者を受け入れる 「町屋 Chouse」の比グなど開放型の空間と集住体のッバーの気質 が、 $C C \Rightarrow O C$ への領域の質の变化を可能にしている。

<(3) $\mathrm{CC}+\mathrm{OC} \Rightarrow \mathrm{OC} \frown \sigma$ 変化 $>$

個人の集住体の占用領域が接続する $O C$ 領域と一体となり、全体 が OC 領域一と変化する。CC の集住体シバーの友人の来客時などにみ られる変化である。事例では、中庭と一住戸のCC とが一体化して一 つの OC 領域となるものがみられる。 $O C$ 領域と接続している領域で あること、べ壮などの装置が、行動が自然に表出されていく要因と なっている。

\section{<(4) $\mathrm{Pe}+O \mathrm{C} \Rightarrow O C$ への変化 $>$}

個人の領域 $P e$ と接続する $O C$ 領域が一体となって $O C$ 領域に変化 する。事例では居住者間の NT の核となる単身者が居住者や友人を集 めた食事会などを行う時に、食事準備のキースデーショととして自宅を開放 している。また Pe が仕事場の場合は、一日の中で時間帯によって Peから OC に変化する。日中は仕事の打ち合わせや仕事仲間との交 流で常時 $O C$ として開放され、仕事を終えると個人の領域Pe となる。 (3)同様 $O C$ 領域と接続している領域であること、ベンチなどの装置、と 同時にPeの占用者の個人のオープンな気質が変化を可能としている。

\section{6. まとめ}

現状では $○$ 領域をもつ事例はまだ少ないが、近年の $O$ をもつ建
筑家による住宅設計の空間的特徵の全体傾向を把握した上で、Open Common をもつ住宅作品を対象として、生活行為の実態調查から $O C$ の働きと状況変化への適応について分析した。その結果以下の 4 点 が明確になった。

(1)OC 領域での生活行為は従来住宅内で行われていた行為を含めて それ以外の多様な行為がみられ、 $O$ 領域をもつことによる居住 NT の形成の可能性を確認した。現状では「交流」に関する活動が 最も多くみられるが、居住 NT の形成は、自立した生活や子育て 環境を生み出す個人の自立の確立に発展していくことが予想さ れる。

(2)居住补ワークの広がりは個人的行動から集住体間、居住者間や近隣 者とのつなぎ行動、通りがかりの不特定多数の人々のつながりま で確認できた。OC での NT の中核をなす居住者間の行動の表出が 近隣の人たちとの慗がりを生み出し、NT が広がっていく。居住者 間の NT が形成されていることで、安心感や帰属感が生まれ、近 隣の人や不特定多数の人の利用を許容し、 $O C$ 領域が開か九ていく。 (3) OC 領域に該当する場所は住宅外部の庭だけでなく、住宅内空間か ら内外に渡る中間領域、敷地内の住宅外部、敷地外までがみられ た。 $O C$ 領域の通り庭型の空間形状は、 $O C$ 領域や他の住戸の気配 が適度に伝わり、かつ前面道路からも $O C$ 領域に視線が通るため に、最も居住 NT の広がりがあり柔軟に状況変化に適応する形式 であった。

(4)多様な状況に適応するためにみられる $O C$ 領域の変化は、質の変化 によるもの、領域の機能が移行するもの、物理的に領域が広がり 別の領域と合わさるものなどがみられ、平常時とれベン時や利用 者によって柔軟に変化していた。

このように、住宅内外の OC 領域で日常的な個人と他者をつなぐ 多様な居住 NT と広がりがみられ、その状態により領域が形成されて いる実態は、 $\mathrm{nLDK}$ が想定した住宅内の機能分化による室の機能や 核家族生活像とは異なった様相を示していた。本稿の結果により、 既稿にて提示した $O C$ 領域をもつ住居構成琴“のの有効性を確認した。 今後は本稿の $O C$ 領域の実態を踏まえて、 $O C$ 領域が機能し居住祅 トワークの形成を育む、多様な家族に開かれていくための物理的要因や 人的要因（居住者属性）などについて検討し、Open Common の構造 を明らかにする予定である。

表 8 事例にみる OC 領域の状況による領域变化パターン

※レベルは居住NTの広がりを記したもの

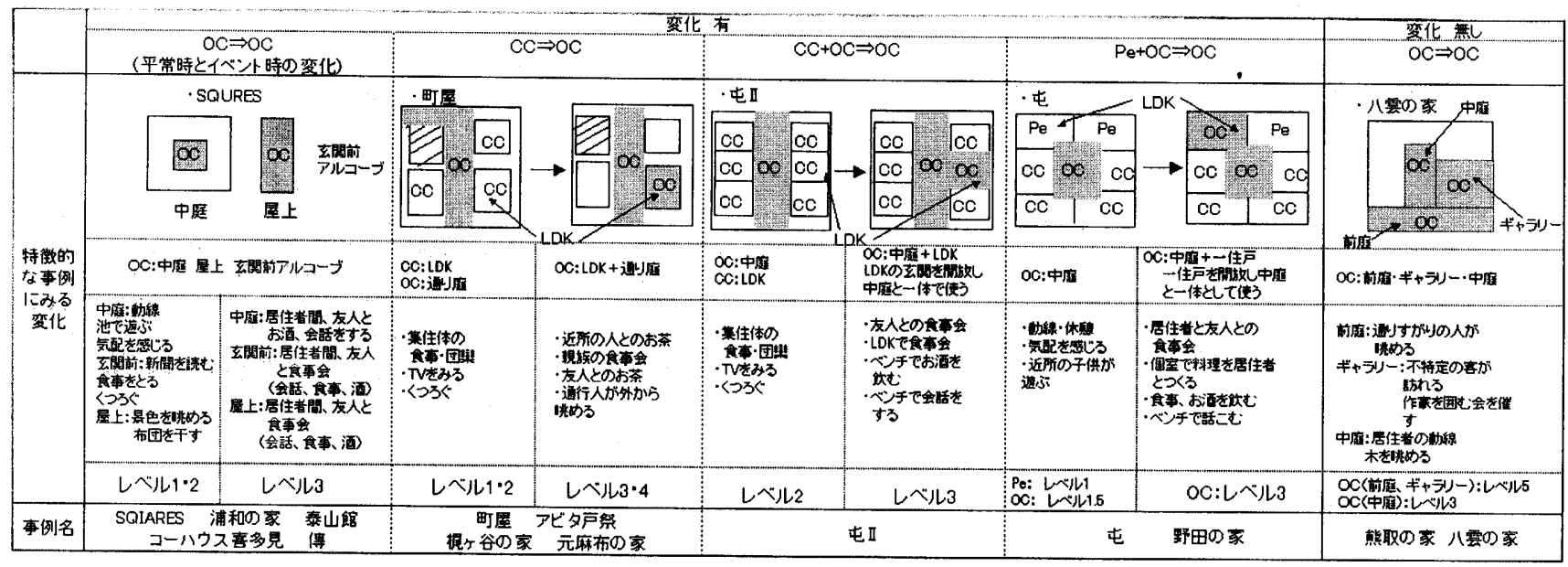


なお本研究は管者が大和ハ市工業株式会社在職時に行った、旧通産省 生活

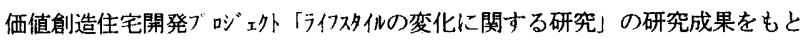
に、発展させたものである。

\section{注}

注 1）参考文献 1）参照

注 2）参考文献 1)にて、居住补鸟とは、住宅を拠点とした居住領域での、

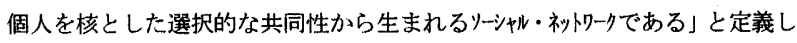
た。また补ワーク居住との違いは、親族との関係だけでなく、友人や近隣の人 さらに都市的なサービスと個人との選択的な関係を取り扱うところにある。

注 3）参考文献 1)にて「open Common とは、個人と個人、個人と地域社会と の接点となる、個の集住体以外の人が利用可能な開かれた共用空間であ る。と定義した。具体的には、日常の生活での自然発生的な交流や州ビ ス を㺨-ズに住宅内の個人の領域八導入する、個人の領域と僌地外の道路とを つなぐ日常の生活動線上の領域である。

注 4）参考文献 1）にて「個人の集住体」とは、同じ住宅（住戸）に住む集団 を意味し、本論では血縁による核家族やいわゆる擬似家族や非血縁による 家族も含めて「個人の集住体了と定義した。

注 5）参考文献 9）10）11）12）参照

注6）参考文献 13）14）15）参照

注 7) 参考文献 16) 17) 18) 参照

注 8）参考文献 19)参照

注 9）1995 2000 年の住宅特集を中心に日経了一析多ヤ一、住宅建築を対象とし、 2001、02、03 年は住宅特集に揭载された建築家の全住宅作品を対象とした。 1995 2000 年は住宅特集だけでは $O C$ 事例が少なかったため、3つの建筑関 係の雑誌を対象とした。

注 10）抽出した事例はPersonal Territory と Public Territory の間に $\propto C$ 領 域が存在すること、さらに実際に設計者が個人を核とした選択的な関係つ くりを念頭においた設計意図が記事の内容に書かれているもの、もしくは 実際に既に関係がみられると書かれているものを抽出した。

注 11）参考文献 1)にて、居住空䦥の構成領域を Personal Territory $(\mathrm{Pe})$, Closed Common (CC) , Open Common (OC) , Public Territory $(\mathrm{Pu})$ と した。構成領域の組以合わせ 4 タイ (依存型、自足型、共用型、適応型)

と動線の選択性の有無により、Pe から Puまでの構成頒域のつながりによる 7 つ配列夕イ゙を提案した。

注 12）複数の $O C$ をもつ事例がみられることから、事例数は 92 だが、 $O C$ 領域 の数は 113 である。

注 13）参考文献 20)では、外部空間と建物の配列を包含、隣接、被包含に分 けている。本稿では、 $O C$ 領域の空間形状を参考文献 20)の外部空間にみた て、隣接を前庭型と通り庭型とにわ忖 4 つの形状夕价による空間形状の傾向 をみる。

注 14）参考文献 1)にて、社会生活基本調查の生活行為分類項目から居住补り 一の働きに該当する生活行為を抽出した。気配を感じる」は社会生活基本 調查項目にはないが、なにげない交流をうながし適度な距離を保つ行為、 として追加した。「交際・つきいいについては、さらに具体的に「会話」 「食事」「接客」「遊び」に分類した。

注 15）七アリリが調查対象者 44 人が $O C$ 領域で行っている生活行為や目整行為に ついて、行為項目別に加小した。加小方法は対象者ごとに「その行為を行っ た」「その行為を見かけた」と答えた行為についてそれぞれ1と加小し、そ の合計人数を生活行為別数とする。但し、目慗した行為については、同じ 事例において複数の人が同じ行為を目繋した場合は 1 として加快した。

注 16）行われている行為が、何日圈きに行われているのかを行為頻度として みる。例えば、表 4 内の「共同調理」は 3 人の人が週一回、5人の人が月に 1. 2 回行っていることを示す。

注 17）各ベ川は、ある状況においての利用者を示したものである。い゙ル1な ら個人のみの利用、以゙ル5の場合は個人から不特定多数の人が一緒に利用 している居住 NT の状況をしめしている。

\section{参考文献}

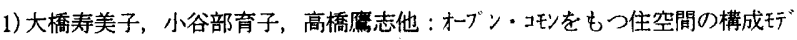
Wの考察, 日本建築学会計画系論文集, 第 577 号, pp. 17-23，2004.3

2) 大橋寿美子，高橋䲽志：これからの家族と住宅の移行一住宅提案にみられ る生活·空間類型の分析から一，日本建築学会技術報告集第 8 号, pp. 163-168, 1999.6

3) 策原聡子, 大橋寿美子, 小泉雅生: 変わる家族と変わる住まい, 彰国社 2002 4) 大橋寿美子, 高橋鷹志他：これからの家族と住宅の移行 〜これからの家 族像の設定〜, 日本建築学会大会学術講演梗概集 E-2 分冊, pp. 263-264, 1999. 9

5）大橋寿美子，高橋鷹志他：これからの家族と住宅の移行一住宅事例にみ る開かれた共用空間の考察 その 1 日本建築学会大会学術講演梗概集 E-2 分 冊, pp. 83-84, 2001.9

6)大橋寿美子，小谷部育子：これからの家族と住宅の移行に関する研究 住 宅事例にみる開かれた共用空間の考察 その 2 日本建築学会大会学術講演 梗概集 E-2 分冊, pp. 7-8, 2002.8

7）秋葉康則，大橋寿美子他 : 生活価値の変化に伴う新しい住要求に関する研 究その 1 その 2 その 3 日本建築学会大会学術講演梗概 $\mathrm{E}-2$ 分冊, pp. 155-160, 1998.9

8）塩野禎隆，大橋寿美子他：生活価值の変化に伴う新しい住要求に関する研 究 その 4 日本建築学会大会学術梗概 E-2 分冊, pp. 257-258, 1999.9

9)小林秀樹 : 集住のなわばり学, 彰国社, 1992

10)小林秀樹、鈴木成文 : 集合住宅における共用領域の形成に関する研究一そ の 1 共有領域の構造一, 日本建築学会論文報告集, 第 307 号, pp102 $111,1981.9$

11)小林秀樹、鈴木成文 : 集合住宅における共用領域の形成に関寸る研究一そ の 2 建築形態の影響一、日本建築学会論文報告集、第 319 号、pp121 131、 1982.9

12)小林秀樹 : 現代住居における場の支配形態一住居における生活領域に関す る研究その1, 日本建築学会論文報告集, 第 468 号, P. $65,1995.2$

13) 山崎さゆり，高橋公子：時間量による生活の類型化一生活時間からみた行 動と滞留空間の対态関係に関する研究 その1-日本建築学会計画系論文 集，第 491 号，pp. 67-74，1997. 1

14) 山崎さゆり，高橋公子：行動類型と空間類型の対応関係一生活時間からみ た行動と滞留空間の対応関俰に関する研究 その 2一日本建築学会計画系 論文集，第 504 号，pp. 111-118，1998.2

15）山崎さゆり，高橋公子：生活時間のクダ別事例分析一生活時間からみた行 動と滞留空間の対応関倸に関する研究 その3-日本建築学会計画系論文 集, 第 538 号, pp. 61-68, 2000. 12

16) 永峰麻衣子、小谷部育子他：「現代東京人」の居場所について一都市単身 居住者の噮境行動に関する研究一 日本建築学会大会学術講演梗概, E-1 分 冊, p. 1061， 1999 年

17) 永峰麻衣子、西出和彦他: 東京における生活頒域に関する考察 一都市単 身居住者の環境行動に関寸る研究 その 2 日本建築学会大会学術譜演梗概， E-2 分冊, p. 37, 2001 年

18) 永峰麻衣子、西出和彦他 : 住居を中心とした行動環境と勤労夕们における 生活形成梯態について都市単身居住者の環境行動に関寸る研究 その $3 \mathrm{E}-2$ 分冊, p. 289, 2003 年

19)䮐 弘志, 外山 義他: 個室型特別養護老人ホームにおけける個室内の個人 的領域形成に関寸る研究日本建築学会計画系論文集, 第 500 号, pp. 133 、 1997. 10

20) 日本建築学会編 : 建築設計資料集成 総合編, 丸善, 2001, pp. 248 21 ) 住環境の計画編集委員会編: 住環境の計画 2 住宅を計画する, 彰国社 2002, pp. 28 